\section{MS30-P4 Synthesis and crystal structures of new di- and polynuclear silver(I) saccharinate complexes with tertiary monophosphanes \\ Orhan Buyukgungor ${ }^{1}$, Veysel T. Yılmaz}

1. Department of Physics, Faculty of Arts and Sciences, Ondokuz Mayis University, 55159 Samsun, Turkey.

2. Department of Chemistry, Faculty of Arts and Sciences, Uludag University, 16059 Bursa, Turkey.

email: orhanb@omu.edu.tr

Over the years there has been a continuous interest in the biological activity of silver(I) metal complexes. Recently, we reported a number of silver(I) sac and found that these complexes have significant antibacterial and anticancer activities [1]. As an extension of our studies, in this work we synthesized and studied the crystal structures of four new silver(I) sac complexes containing the monophosphane ligands, namely $\left[\mathrm{Ag}(\mu-\mathrm{sac})\left(\mathrm{PPh}_{3}\right)\right]_{2}$ (1), $\left[\mathrm{Ag}(\mu \text {-sac })\left(\mathrm{PPh}_{2} \mathrm{Cy}\right)\right]_{2}(\mathbf{2}),\left[\mathrm{Ag}(\mu \text {-sac })\left(\mathrm{PPhCy}_{2}\right)\right]_{2}(\mathbf{3})$ and $\left[\mathrm{Ag}(\mu-\mathrm{sac})\left(\mathrm{PCy}_{3}\right)\right]_{\mathrm{n}} \quad$ (4), where $\mathrm{PPh}_{3}=$ triphenylphosphane,

cyclohexyldiphenylphosphane, dicyclohexylphenylphosphane $\mathrm{PPh}_{2} \mathrm{Cy}$ $\begin{array}{ll}\mathrm{PPhCy}_{2} & = \\ \text { and } \mathrm{PCy}_{3} & =\end{array}$ tricyclohexylphosphane (see Figure.) The silver(I) ion in complex 1 is coordinated by a sac ligand via the $\mathrm{N}$ atom and $\mathrm{PPh}_{3}$ ligand, forming a $\left[\mathrm{Ag}(\mathrm{sac})\left(\mathrm{PPh}_{3}\right)\right]$ unit and the $\left[\mathrm{Ag}(\mathrm{sac})\left(\mathrm{PPh}_{3}\right)\right]$ units are further doubly bridged by relatively long $\mathrm{Ag}-\mathrm{O}_{\text {sulf }}$ bonds, leading to a dinuclear structure $\left[\mathrm{Ag}(\mathrm{sac})\left(\mathrm{PPh}_{3}\right)\right]_{2}$. The dimeric units of complex 1 are connected by weak intermolecular interactions such as $\mathrm{C}-\mathrm{H} . . \mathrm{O}, \pi(\mathrm{sac}) \ldots \pi\left(\mathrm{PPh}_{3}\right)$ and $\mathrm{CH} \ldots \pi$ ( $\mathrm{PPh}_{3}$ ). Complexes 2 and 3 show a structural similarity. Each complex also exhibits significant interactions between the silver(I) centers. The $\mathrm{Ag}-\mathrm{Ag}$ distances are comparable with literature but significantly smaller than that found in other dinuclear sac complexes showing strong argentophilic interactions with $\mathrm{Ag}-\mathrm{Ag}$ distances around $2.90 \AA$. Complex 4 is a one-dimensional metallopolymer in which the silver(I) ions are bridged by the sac ligands through the imino $\mathrm{N}$ and the carbonyl $\mathrm{O}$ atoms, leading to a linear one dimensional polymeric chain running along the b-axis. In all four crystal structures, the di- and polynuclear structures are achieved by the N/O bridging mode of the sac ligand. All phosphane ligands act as a monodentate donor through the $\mathrm{P}$ atom. Complexes 2 and 3 exhibit strong argentophilic interactions.

\section{References:}

[1] V.T. Yilmaz, E. Gocmen, C. Icsel, M. Cengiz, S.Y. Susluer, O. Buyukgungor, J. Biol. Inorg. Chem. 19 (2014)

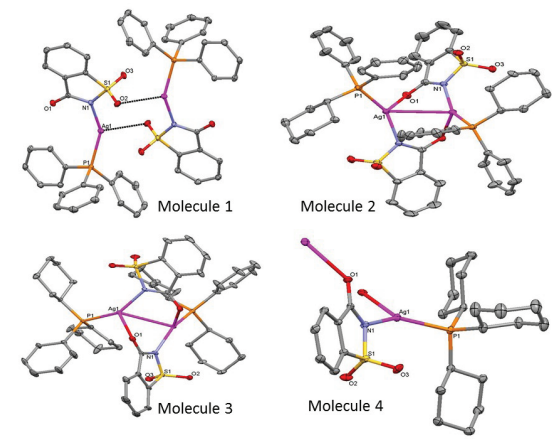

Figure 1. View of the molecular structures. Hydrogen atoms were omitted for clarity. The probability level of thermal ellipsoids are $30 \%$.

Keywords: Crystal structure, Saccharinate, Phosphine 